\title{
PENGARUH KONSENTRASI KULIT SINGKONG DAN SUMBER NITROGEN TERHADAP PRODUKSI GLUKOAMILASE OLEH Aspergillus awamori KT-11PADA SUBMERGED FERMENTASI
}

\section{(Effect of Cassava Peelfor Glucoamylase Production by Aspergillus awamori KT-11 in Submerged Fermentation)}

\author{
U. Perwitasari ${ }^{1}$, S. Amanah ${ }^{1}$, M. D. Wahidiyah ${ }^{2}$, Nuryati ${ }^{1}$, R. Melliawati ${ }^{1}$,

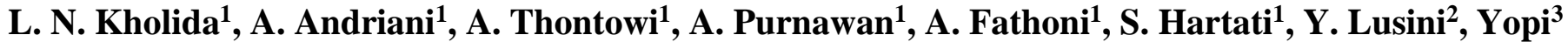 \\ ${ }^{1}$ Pusat Penelitian Bioteknologi, LIPI, Jl. Raya Bogor Km 46, Cibinong, Bogor 16911, Indonesia \\ ${ }^{2}$ Akademi Kimia Analisis Caraka Nusantara, Komplek Timah, Jl. Tugu Raya, Cimanggis, Depok 16951 Indonesia \\ ${ }^{3}$ Pusat Riset dan Pengembangan Sumber Daya Manusia, Badan Standardisasi Nasional, Kompleks PUSPIPTEK \\ Gedung 420, Setu Tangerang Selatan 15314 Indonesia \\ email: uripperwitasari@gmail.com
}

Diterima 14 April 2020, Revisi akhir 04 Desember 2020, Disetujui 07 Desember 2020

\begin{abstract}
ABSTRAK. Bahan baku yang mahal dalam produksi glukoamilase mengakibatkan harga jual glukoamilase tinggi. Pemanfaatan biomassa tinggi karbohidrat diharapkan dapat menjadi alternatif bahan baku untuk menurunkan biaya produksi enzim tanpa menurunkan kualitas dari produk yang dihasilkan. Aspergillus awamori KT-11 diketahui mampu memproduksi glukoamilase dengan memanfaatkan limbah biomassa. Tujuan penelitian ini adalah optimasi produksi glukoamilase dari A. awamori KT-11 dengan memanfaatkan limbah kulit singkong sebagai substrat alternatif dengan berbagai sumber nitrogen melalui Submerged Fermentation $(\mathrm{SmF})$. Variabel yang dilakukan pada penelitian ini yaitu konsentrasi kulit singkong (5-30\%), sumber nitrogen (kasein hidrolisat, yeast extract dan natrium nitrat). Hasil riset menunjukkan konsentrasi kulit singkong dan jenis sumber nitrogen mempengaruhi produksi glukoamilase. Aktivitas glukoamilase optimum diidentifikasi ketika konsentrasi substrat kulit singkong sebesar 10\% yaitu 3984,935 U/L. Penambahan sumber nitrogen yang berbeda mempengaruhi produksi glukoamilase secara signifikan. Penambahan yeast extract meningkatkan aktivitas glukoamilase menjadi 4617,894 U/L.
\end{abstract}

Kata kunci: Aspergillus awamori KT-11, glukoamilase, kulit singkong, submerged fermentasi (SmF)

\begin{abstract}
The expensive price of glucoamylase is due to the high cost of enzyme production. Utilization biomass is expected to be an alternative raw material to reduce the cost of producing enzymes without reducing the quality of the product. Aspergillus awamori KT-11 is known to be able to produce glucoamylase by utilizing biomass waste. This study aimed to optimize glucoamylase production from A. awamori KT-11 by utilizing cassava peel as an alternative substrate with variation nitrogen source through Submerged Fermentation $(\mathrm{SmF})$. Variables carry out in this study were the concentration of cassava peel (5-30\%), nitrogen sources (casein hydrolyzate, yeast extract and sodium nitrate). The results showed in the concentration of cassava peels and nitrogen sources affect glucoamylase production. The optimum glucoamylase activity was 3984,935 U/L in 10\% of cassava peel in medium. The other results showed different sources of nitrogen significantly influence glucoamylase production. The addition of yeast extract increased glucoamylase activity to 4617,894 U/L.
\end{abstract}

Keywords: Aspergillus awamori KT-11, glucoamylase, cassava peel, submerged fermentation (SmF)

\section{PENDAHULUAN}

Amilase memiliki dua kelas utama yaitu $\alpha$ amilase (EC 3.2.1.1) dan glukoamilase (EC 3.2.1.3). Enzim $\alpha$-amilase dapat menghidrolisis pati menjadi maltosa, glukosa dan maltotriosa dengan memutuskan ikatan 1,4- $\alpha$-D-glikosidik diantara unit glukosa yang berdekatan dalam rantai lurus amilosa (Pandey et al., 2000). Glukoamilase 
menghidrolisis unit tunggal glukosa dari ujung gula non pereduksi amilosa dan amilopektin secara bertahap, menghasilkan glukosa sebagai satusatunya produk akhir dari pati dan polimer yang terkait (Anto et al., 2006). Tidak seperti $\alpha$-amilase, sebagian besar glukoamilase juga mampu menghidrolisis ikatan $\alpha-1,6$ pada titik percabangan amilopektin, meskipun pada tingkat yang lebih rendah dari ikatan $\alpha-1,4$.

Glukoamilase dapat diproduksi dengan teknik Submerged Fermentation (SmF) (Wang et al., 2008), Solid State Fermentation (SSF) (Perwitasari et al., 2018) dan liquid fermentation (Fujio \& Morita, 1996). SmF adalah salah satu teknik fermentasi dalam media cair dengan sistem aerasi atau agitasi yang berbeda dengan fermentasi padat (Malakar et al., 2020). Fermentasi jenis ini sangat cocok untuk mikroorganisme yang membutuhkan kadar air tinggi untuk pertumbuhannya (Sundarram \& Krishna Murthy, 2014). Mikroorganisme yang biasanya digunakan untuk memproduksi glukoamilase adalah Aspergillus sp., Rhizopus sp., dan Trichoderma reesei (Pandey et al., 2000). Aspergillus awamori adalah isolat berasal dari Indonesia hasil isolasi dari udara teridentifikasi mampu memproduksi enzim glukoamilase (Matsubara et al., 2004).

Komposisi medium merupakan salah satu syarat yang mendukung pertumbuhan mikroorganisme dalam memproduksi enzim. Pada umumnya, sumber karbon yaitu pati sudah terkandung dalam medium produksi. Namun, masih diperlukan tambahan campuran mineral lainnya. Untuk memenuhi komposisi medium tersebut, dibutuhkan biaya yang tinggi untuk produksi enzim. Oleh karena itu, bahan yang digunakan untuk memproduksi enzim glukoamilase ini berpengaruh untuk menurunkan biaya produksi (Ubalua, 2014). Efisiensi dan penurunan biaya produksi dapat dicapai dengan penggunaan medium alternatif sebagai sumber karbon dan mineral (Luo et al., 2015).

Singkong merupakan salah satu komoditas pertanian yang cukup penting di dunia baik dari segi sumber pangan maupun sumber pakan (Balagopalan et al., 2018). Hal itu disebabkan oleh kandungan karbohidrat sebesar 85,97-89,32\%, protein 1,06-3,55\%, serat kasar 5,44-8,63\%, kadar air 69,03-72,00\% dan lemak 0,40-1,33\% (Otache et al., 2017). Produksi singkong di Indonesia mencapai 18,9 juta ton per tahun dan menghasilkan limbah kulit singkong mencapai 1,5-2,8 juta ton. Padahal, kulit singkong mengandung protein sebesar $3,97 \%$, lemak $0,86 \%$ dan pati $60,68 \%$
(Souto et al., 2017). Berdasarkan data tersebut, kulit singkong berpotensi untuk dijadikan medium alternatif untuk pertumbuhan mikroorganisme selama proses fermentasi, sebagai pengganti media instan yang harganya mahal Woiciechowski et al., 2002; Souto et al., 2017. Beberapa riset yang telah memanfaatkan kulit singkong sebagai substrat untuk bioproduk diantaranya adalah produksi asam sitrat (Adeoye et al., 2015), bioetanol (Adekunle et al., 2016), gula untuk fermentasi (Bayitse et al., 2015); (Souto et al., 2017) dan amilase (Sani et al., 1992).

Penelitian terdahulu dalam Perwitasari et al. (2018) telah melaporkan produksi glukoamilase menggunakan kulit singkong dengan fermentasi padat. Penelitian ini bertujuan untuk meningkatkan aktivitas glukoamilase oleh Aspergillus awamori KT-11 melalui fermentasi semipadat atau SmF dengan menambahkan berbagai sumber nitrogen. Hal ini didasari dari laporan Rodrigues et al. (2017) yang menyatakan bahwa stabilitas enzim dari produksi SmF lebih stabil dari enzim yang didapat dari SSF.

\section{METODE PENELITIAN}

Desain riset yang dilakukan pada penelitian ini menggunakan metode Rancangan Acak Lengkap (RAL) dengan satu variabel bebas. Pada percobaan pengaruh kulit singkong, kondisi fermentasi sebagai variabel tetap dan variasi konsentrasi kulit singkong sebagai variabel bebas $(5 \%, 10 \%, 15 \%, 20 \%, 25 \%$ dan $30 \%)$. Pada percobaan pengaruh sumber nitrogen, variabel bebasnya adalah sumber nitrogen $(0,2 \%$ kasein hidrolisat, $0,1 \%$ yeast extract dan $0,32 \%$ natrium nitrat). Pengolahan data dilakukan dengan uji Analisis of variance (Anova) satu arah menggunakan Microsoft Excel 2010. Nilai untuk uji signifikansi adalah $\mathrm{p}<0,05$. Seluruh percobaan dilakukan sebanyak tiga kali ulangan.

Isolat Aspergillus awamori KT-11 koleksi Pusat Penelitian Bioteknologi LIPI, Cibinong Bogor, Jawa Barat, Indonesia. Kulit singkong yang digunakan berasal dari umbi singkong koleksi kebun plasma nutfah Pusat Penelitian Bioteknologi LIPI jenis Menti. Potato Dextrose Agar (PDA) (Bacto Difco), casein hidrolisat (Oxoid), yeast extract (Bacto Difco), serta bahan kimia lain dengan kualitas pro analisis.

\section{Preparasi Sampel Kulit Singkong}

Kulit singkong yang diperoleh dicuci bersih dan ditiriskan. Kemudian kulit singkong dirajang 
halus lalu diblender tanpa menambahkan air. Kulit singkong siap digunakan sebagai substrat fermentasi.

\section{Peremajaan Kultur Isolat}

Isolat yang akan digunakan diremajakan terlebih dahulu dari stok kultur isolat A. awamori KT-11. Sebanyak satu ose stok isolat diambil kemudian digoreskan ke media agar miring PDA. Kultur kemudian diinkubasi selama 5 hari pada suhu ruang setelah itu isolat siap digunakan (Sani et al., 1992). Pemanenan spora dari kultur dilakukan dengan menambahkan $5 \mathrm{~mL}$ akuades steril (Ubalua, 2014)

\section{Pengaruh Konsentrasi Kulit Singkong}

Tahapan riset pertama yaitu menentukan konsentrasi kulit singkong sebagai sumber karbon untuk produksi enzim glukoamilase. Pada riset ini, kulit singkong sebagai substrat ditambahkan ke dalam buffer sitrat fosfat $\mathrm{pH} 4,8$ dengan variasi konsentrasi $5 \%, 10 \%, 15 \%, 20 \%, 25 \%$ dan $30 \%$ (Moorthy, 2002). Media kemudian disterilisasi pada kondisi suhu $121{ }^{\circ} \mathrm{C}$, tekanan $1 \mathrm{~atm}$, selama 15 menit (Najafpour, 2015). Setelah dingin, masing-masing media ditambahkan 5\% (v/v) larutan spora A. awamori KT-11. Kemudian, kultur diinkubasi di dalam shaker dengan kecepatan 120 rpm pada suhu ruang. Setelah lima hari, kultur dipanen untuk melihat aktivitas enzim glukoamilase dari berbagai konsentrasi kulit singkong. Setiap kultur maupun uji aktivitas enzim dilakukan sebanyak tiga kali ulangan. Konsentrasi kulit singkong yang menghasilkan aktivitas glukoamilase tertinggi dipilih sebagai variabel sumber karbon pada tahapan riset selanjutnya (Wang et al., 2008)

\section{Pengaruh Sumber Nitrogen}

Tahapan selanjutnya yaitu melihat pengaruh penambahan sumber nitrogen terhadap produksi glukoamilase. Terdapat tiga jenis sumber nitrogen yang ditambahkan yaitu $0,2 \%$ kasein hidrolisat, $0,1 \%$ yeast extract dan $0,32 \%$ natrium nitrat (Pedersen \& Nielsen, 2000). Masing-masing sumber nitrogen ditambahkan ke media yang telah mengandung kulit singkong sebagai sumber karbon. Tahapan ini dibuat tiga kali pengulangan (Uçkun Kiran et al., 2014). Setelah semua siap, media disterilisasi pada kondisi suhu $121{ }^{\circ} \mathrm{C}$, tekanan $1 \mathrm{~atm}$, selama 15 menit. Setelah media dingin ditambahkan spora sebanyak $2 \mathrm{~mL}$. Kultur diinkubasi selama 5 hari di dalam shaker dengan kecepatan 120 rpm pada suhu ruang kemudian diuji aktivitas enzimnya.

\section{Penentuan Aktivitas Enzim}

Substrat yang digunakan untuk aktivitas enzim adalah 5\% soluble starch dalam buffer sitrat fosfat 4,8. Uji aktivitas enzim dilakukan mereaksikan $400 \mu \mathrm{L}$ substrat dengan $100 \mu \mathrm{L}$ crude enzim pada suhu $60{ }^{\circ} \mathrm{C}$ selama 1 jam. Sampel kemudian disentrifugasi dengan kecepatan 10000 rpm selama 15 menit pada suhu $4{ }^{\circ} \mathrm{C}$ (Perwitasari et al., 2018). Filtrat kemudian dihitung kadar gulanya dengan metode Somogyi, warna yang terbentuk diukur serapannya dengan menggunakan spektrofotometer pada panjang gelombang $\lambda 500$ nm (Somogyi, 1952). Satu 1 mikromol gula reduksi yang dihasilkan per menit dinyatakan sebagai satu unit aktivitas glukoamilase.

$$
\text { Aktivitas enzim }\left(\frac{\mathrm{U}}{\mathrm{mL}}\right)=\frac{(\text { Konsentrasi glukosa } \times \text { FP x1000) }}{\text { (waktu reaksi } \mathrm{x} \text { Mr Glukosa) }}
$$

\section{Produksi Gula}

Penentuan produksi gula dari pati dengan menggunakan enzim glukoamilase dengan aktivitas tertinggi. Sebanyak 30 gram tepung pati ditimbang, ditambahkan $100 \mathrm{~mL}$ aquades, dididihkan sampai tergelatinisasi dan diinkubasi di waterbath suhu $60{ }^{\circ} \mathrm{C}$. Setelah tepung pati stabil, ditambahkan $10 \mathrm{~mL}$ crude enzim dan diinkubasi kembali pada suhu $60{ }^{\circ} \mathrm{C}$ selama 72 jam. Reaksi dimatikan dengan memanaskan sampel selama 10 menit. Sampel disentrifugasi pada $10000 \mathrm{rpm}, 4{ }^{\circ} \mathrm{C}$ selama 15 menit. Selanjutnya, Selanjutnya, supernatan diuji kadar gula pereduksi dengan metode Dinitrosalysilic acid (DNS) (Miller, 1959) dan gula total dengan metode fenol-asam sulfat (Dubois et al., 1956).

\section{Dextrose Equivalen dan Derajat Polimerisasi}

Gula hasil hidrolisis pati ditentukan nilai Dextrose Equivalen (DE) dan nilai Derajat Polimerisasi (DP). Nilai DE dihitung berdasarkan pembagian antara jumlah gula pereduksi dibagi dengan jumlah gula total dari pati (Zhao et al., 2015). Sedangkan nilai DP dihitung berdasarkan pembagian gula total dengan gula pereduksi. Analisis gula pereduksi menggunakan metode DNS sedangkan analisis gula total menggunakan metode fenol sulfat.

$$
\text { Derajat Polimerisasi (DP) }=\frac{\text { gula total }}{\text { gula pereduksi }}
$$


Dextrose Equivalen $(\mathrm{DE})=100 \times \frac{180}{(180 \times \mathrm{DP})-(18 \times(\mathrm{DP}-1))}$

\section{HASIL DAN PEMBAHASAN}

\section{Peremajaan Kultur Isolat}

Peremajaan isolat A. awamori KT-11 dilakukan sebelum digunakan untuk mendapatkan kondisi isolat yang aktif sehingga optimal dalam memproduksi enzim. Pertumbuhan spora pada media PDA sudah terlihat dari hari ketiga inkubasi. Spora A. awamori KT-11 terlihat hitam sempurna setelah lima hari inkubasi (Gambar 1). Media yang telah dipenuhi spora siap untuk dipindahkan ke media yang lebih kompleks dari PDA. Komposisi media yang lebih kompleks dapat menginduksi produksi enzim amilase (Ubalua, 2014). A. awamori KT-11 diketahui memiliki kelompok enzim amilolitik seperti amilase dan glukoamilase (Anindyawati et al., 1998; Matsubara et al., 2004).

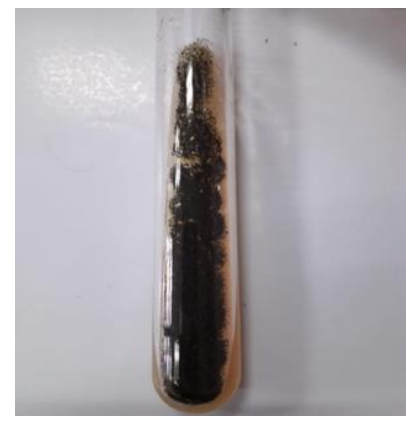

Gambar 1. Aspergillus awamori KT-11 pada media Potato Dextrose Agar

\section{Pengaruh Kulit Singkong Sebagai Substrat}

Sani et al., (1992) melaporkan produksi enzim amylase dengan memanfaatkan $2 \%$ tepung kulit singkong sebagai substrat. Kulit singkong memiliki kadar air yang tinggi sekitar 70\% (Otache et al., 2017). Pada penelitian ini kami menggunakan kulit singkong segar sehingga kami menggunakan konsentrasi substrat yang yang lebih tinggi dibandingkan riset yang dilakukan oleh Sani et al. Penanaman isolat pada media pertumbuhan enzim ini dilakukan dalam beberapa konsentrasi substrat, yaitu 5\%, 10\%, 15\%, 20\%, 25\% dan 30\%. Konsentrasi substrat di atas $30 \%$ menyebabkan media menjadi padat sehingga sulit untuk dilakukan proses agitasi. Kelarutan pati singkong berkisar antara 25-48\% (Moorthy, 2002) Perbedaan kelarutan ini dipengaruhi oleh karakteristik amilosa dan amilopektin pada singkong (Kusumayanti et al., 2015). Tahapan riset optimasi pemilihan konsentrasi substrat dilakukan hanya dengan satu variabel bebas yaitu konsentrasi kulit singkong tanpa ada penambahan sumber nitrogen. Metode riset yang dipilih adalah RAL karena kondisi percobaan yang bersifat homogen serta pengamatan dilakukan secara berulang (Widiharih, 2001).

Gambar 2 menunjukkan hasil uji aktivitas enzim dengan variasi konsentrasi substrat memperlihatkan penambahan konsentrasi substrat tidak dapat meningkatkan aktivitas enzim glukoamilase. Nilai optimumnya pada konsentrasi substrat $10 \%$ tanpa penambahan sumber nitrogen dengan aktivitas enzim sebesar 3984,94 U/L. Aktivitas enzim tidak bertambah lagi dan menunjukkan pola yang konstan pada konsentrasi substrat lebih dari $10 \%$. Hal ini dapat disebabkan oleh media tumbuh A. awamori KT-11 yang telah jenuh dengan substrat, karena pemberian substrat yang terbatas dapat menginduksi produksi enzim amilase (Sani et al., 1992).

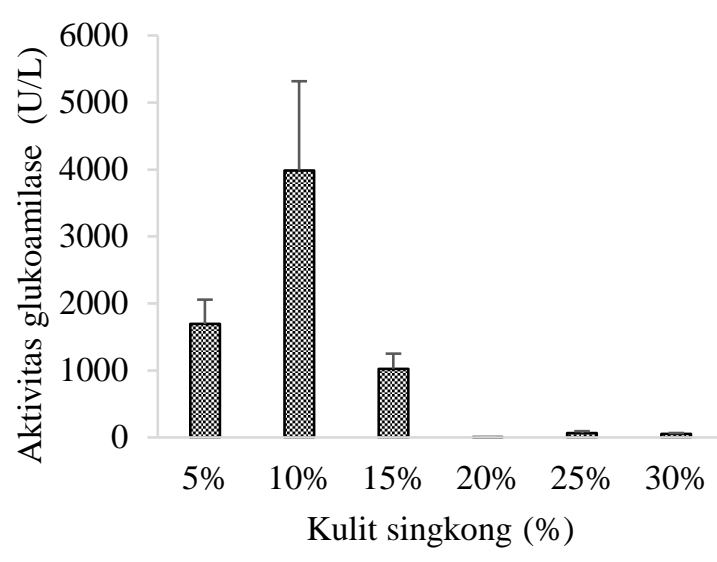

Gambar 2. Pengaruh konsentrasi kulit singkong terhadap produksi glukoamilase

Wang et al. (2008) dalam penelitiannya menjelaskan efek konsentrasi limbah makanan pada aktivitas enzim glukoamilase yang dihasilkan oleh Aspergillus niger, aktivitas glukoamilase pada konsentrasi limbah makanan 1,25\%, 2,50\%, 3,75\% dan $6,25 \%$ secara berturut-turut adalah $33 \mathrm{U} / \mathrm{mL}$, $126 \mathrm{U} / \mathrm{mL}, 50 \mathrm{U} / \mathrm{mL}$ dan $49 \mathrm{U} / \mathrm{mL}$. Hal ini menunjukkan bahwa aktivitas enzim akan meningkat dan menurun seiring dengan penurunan nutrient dan autolisis dari substrat.

Hasil uji Anova pengaruh kulit singkong terhadap produksi glukoamilase memiliki nilai $\mathrm{F}$ 
hitung 20 lebih tinggi dibandingkan dengan $\mathrm{F}$ tabel 3. Hal ini menunjukkan bahwa variasi kulit singkong sebagai substrat berpengaruh terhadap produksi glukoamilase. Nilai $\mathrm{P}$ yang dihasilkan kurang dari 0,05 menunjukkan konsentrasi kulit singkong sebagai substrat memiliki pengaruh yang signifikan terhadap produksi glukoamilase. Konsentrasi kulit singkong yang mampu menghasilkan aktivitas glukoamilase tertinggi $(10 \%)$ selanjutnya digunakan sebagai sumber karbon sebagai variabel tetap pada tahapan riset selanjutnya yaitu melihat pengaruh sumber nitrogen.

\section{Pengaruh Sumber Nitrogen}

Sumber nitrogen yang digunakan yaitu kasein hidrolisat, yeast extract dan natrium nitrat $\left(\mathrm{NaNO}_{3}\right)$. Kasein hidrolisat diketahui sebagai sumber nitrogen kompleks karena mengandung asam amino bebas dan karenanya diharapkan menjadi sumber yang sangat baik untuk produksi protein (Pedersen \& Nielsen, 2000). Yeast extract diketahui sering digunakan sebagai sumber nitrogen dalam produksi protein industri (Sindhu et al., 2016). Natrium nitrat diketahui merupakan sumber nitrogen anorganik yang sering digunakan dalam banyak proses fermentasi (Bruinenberg et al., 1983; Sundarram \& Krishna Murthy, 2014).

Gambar 3 menunjukkan bahwa aktivitas enzim tertinggi terdapat yeast extract dengan aktivitas sebesar 4617,894 U/L. Sumber nitrogen ini meningkatkan produktivitas glukoamilase oleh A. awamori KT-11dibandingkan kasein hidrolisat dan natrium nitrat. Hal ini dapat disebabkan oleh peran yeast extract sebagai sumber karbon dan sumber nitrogen. Bahan ini juga diketahui dapat menginduksi produksi amilase (Sindhu et al., 2016).

Pada hasil Anova pengaruh sumber nitrogen, nilai $\mathrm{F}$ hitung lebih besar dari nilai $\mathrm{F}$ tabelnya serta nilai $\mathrm{P}$ kurang dari 0,05 . Hasil ini membuktikan bahwa sumber nitrogen mempengaruhi produksi glukoamilase secara signifikan. Walaupun aktivitas glukoamilase tertinggi dihasilkan dari yeast extract, namun pada tahapan riset selanjutnya kami menggunakan natrium nitrat sebagai sumber nitrogen untuk produksi glukoamilase. Hal tersebut bertujuan untuk efisiensi biaya produksi glukoamilase. Harga natrium nitrat lebih murah daripada yeast extract, namun mampu menghasilkan aktivitas enzim yang hampir sama.

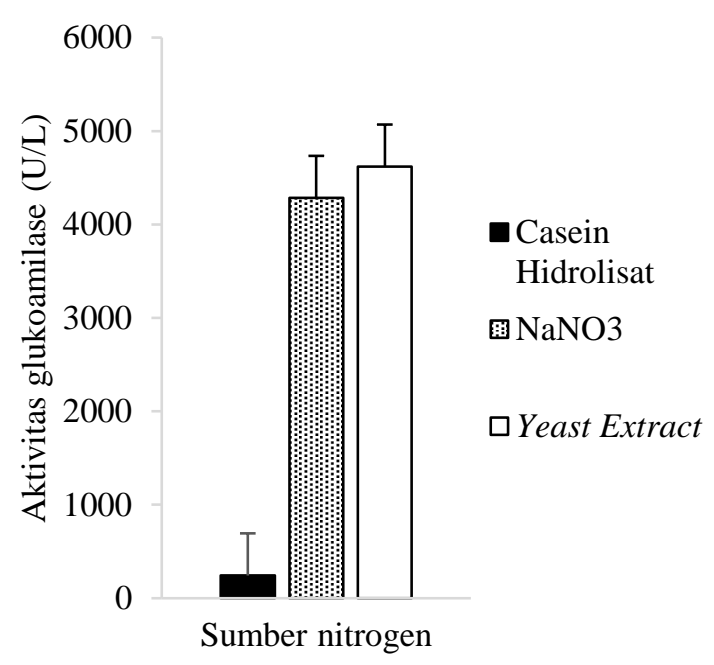

Gambar 3. Pengaruh sumber nitrogen terhadap produksi glukoamilase dengan konsentrasi kulit singkong $10 \%$

\section{Aplikasi Glukoamilase}

Glukoamilase dari A. awamori KT-11 diuji kemampuannya untuk memproduksi gula cair dengan menghidrolisis pati singkong. Hidrolisis pati singkong menghasilkan gula sederhana berupa gula pereduksi, sehingga pengukuran gula pereduksi tersebut dapat dijadikan alat pengontrol kualitas hasil. Pada reaksi hidrolisis, derajat konversi pati menjadi dekstrosa dinyatakan dengan Dextrose Equivalent (DE). DE merupakan jumlah ujung gugus aldehid dari gula pereduksi yang ada dalam produk gula dibagi jumlah gula total dari pati (Takeiti et al., 2010). Nilai dalam penelitian ini sebesar 28,33\% (Tabel 1).

Tabel 1. Analisis sirup gula yang dihasilkan

\begin{tabular}{lc}
\multicolumn{1}{c}{ Parameter } & Nilai \\
\hline Gula Pereduksi & $173,36 \pm 7,3 \mathrm{~g} / \mathrm{L}$ \\
\hline Gula Total & $44,64 \pm 0,2 \mathrm{~g} / \mathrm{L}$ \\
\hline $\begin{array}{l}\text { Dextrose Equivalent } \\
\text { (DE) }\end{array}$ & $28,33 \pm 0,7$ \\
\hline $\begin{array}{l}\text { Derajat Polimerisasi } \\
\text { (DP) }\end{array}$ & $3,88 \pm 0,1$ \\
\hline
\end{tabular}

Jumlah DE lebih dari 20\% suatu produk sudah dinyatakan sebagai sirup glukosa (Hull, 2010). Gula pereduksi $173,36 \mathrm{~g} / \mathrm{L}$ menunjukkan bahwa dalam produk hidrolisat (filtrat) yang dihasilkan, terdapat gula pereduksi (glukosa) sebesar 173,36 g/L, gula total 44,64 g/L 
menunjukkan bahwa konsentrasi gula total dalam produk hidrolisat pati.

Pati yang dihidrolisis menghasilkan produk berupa maltodekstrin dengan nilai DE minimal 20 (Hull, 2010). Derajat polimerisasi (DP) menyatakan jumlah unit monomer dalam satu molekul. DP 3,88 mengindikasikan banyaknya monomer maltotriosa-maltotetraosa dalam produk hidrolisat. Nilai DP dan DE dari maltodekstrin dalam penelitian ini sesuai dengan penelitian sebelumnya bahwa nilai DE $30 \%$ memiliki nilai DP antara 2-30. Nilai DP yang tinggi menunjukkan banyaknya jumlah gula monomer yang terikat untuk menjadi polimer. Semakin tinggi nilai DP, maka rantai gula tersebut semakin panjang. Sehingga, semakin banyak pula ruang di gula oligomer yang mampu mengikat air. Oleh sebab itu, semakin tinggi nilai DP maka produk gula yang dihasilkan akan lebih mudah menyerap air (Saavedra-Leos et al., 2015).

\section{KESIMPULAN}

Media kulit singkong dapat digunakan sebagai pengganti media sintetik yang harganya cukup mahal untuk memproduksi enzim glukoamilase menggunakan metode submerged fermentasi (SmF). Aktivitas glukoamilase tertinggi sebesar 4617,894 U/L dihasilkan ketika konsentrasi substrat kulit singkong sebesar 10\%, sumber nitrogen yang berasal dari yeast extract dan waktu inkubasi selama 120 jam. Hasil studi dengan metode RAL serta analisis ANOVA menunjukkan produksi glukoamilase dipengaruhi oleh konsentrasi kulit singkong, serta jenis nitrogen secara signifikan. Aplikasi dari glukoamilase dicoba untuk menghidrolisis pati singkong yang telah digelatinisasi. Glukoamilase yang dihasilkan mampu menghidrolisis pati singkong menjadi menjadi gula sederhana glukosa selama 72 jam dengan nilai DE $28,33 \%$ dan nilai DP 3,88 .

\section{DAFTAR PUSTAKA}

Adekunle, A., Orsat, V., \& Raghavan, V. (2016). Lignocellulosic bioethanol: A review and design conceptualization study of production from cassava peels. Renewable and Sustainable Energy Reviews, 64, 518-530. https://doi.org/10.1016/j.rser.2016.06.064

Adeoye, A. O., Lateef, A., \& Gueguim-Kana, E. B. (2015). Optimization of citric acid production using a mutant strain of Aspergillus niger on cassava peel substrate. Biocatalysis and Agricultural Biotechnology, 4(4), 568-574. https://doi.org/10.1016/j.bcab.2015.08.004

Anindyawati, T., Melliawati, R., Ito, K., Iizuka, M., \& Minamiura, N. (1998). Three different types of $\alpha$-amylases from Aspergillus awamori KT-11: their purifications, properties, and specificities. Bioscience, Biotechnology, and Biochemistry, 62(7), 1351-1357. https://doi.org/10.1271/bbb.62.1351

Anto, H., Trivedi, U. B., \& Patel, K. C. (2006). Glucoamylase production by solid-state fermentation using rice flake manufacturing waste products as substrate. Bioresource Technology, 97(10), 1161-1166. https://doi.org/10.1016/j.biortech.2005.05.007

Balagopalan, C., Padmaja, G., Nanda, S. K., \& Moorthy, S. N. (2018). Cassava in food, feed and industry. In Cassava in Food, Feed and Industry. https://doi.org/10.1201/9781351070430

Bayitse, R., Hou, X., Bjerre, A.-B., Saalia, F. K., Arantes, V., Saddler, J., Attahdaniel, B., Adeeyinwo, C., Adetunji, A., Olusunle, S., Adewoye, O., Bokanga, M., Bommarius, A., Katona, A., Cheben, S., Patel, A., Ragauskas, A., Knudson, K., Pu, Y., ... Wang, C. (2015). Optimisation of enzymatic hydrolysis of cassava peel to produce fermentable sugars. $A M B$ Express, 5(1), 60. https://doi.org/10.1186/s13568-015-0146-z

Bruinenberg, P. M., Van Dijken, J. P., \& Scheffers, W. A. (1983). A theoretical analysis of NADPH production and consumption in yeasts. Journal of General Microbiology, 129(4), 953-964. https://doi.org/10.1099/00221287-129-4-953

Dubois, M., Gilles, K. A., Hamilton, J. K., Rebers, P. A., \& Smith, F. (1956). Colorimetric Method for Determination of Sugars and Related Substances. Analytical Chemistry, 28(3), 350-356. https://doi.org/https://doi.org/10.1021/ac60111a0 17

Fujio, Y., \& Morita, H. (1996). Improved glucoamylase production by Rhizopus sp. A-11 using metal-ion supplemented liquid medium. Journal of Fermentation and Bioengineering, 82(6), 554$557 . \quad$ https://doi.org/10.1016/S0922$338 \mathrm{X}(97) 81251-2$

Hull, P. (2010). Glucose Syrups: Technology and 
Applications. In Glucose Syrups: Technology and Applications. https://doi.org/10.1002/9781444314748

Kusumayanti, H., Handayani, N. A., \& Santosa, H. (2015). Swelling Power and Water Solubility of Cassava and Sweet Potatoes Flour. Procedia Environmental Sciences, 23(Ictcred 2014), 164167.

https://doi.org/10.1016/j.proenv.2015.01.025

Luo, H., Liu, H., He, Z., Zhou, C., \& Shi, Z. (2015). Efficient and cost-reduced glucoamylase fedbatch production with alternative carbon sources. Journal of Microbiology and Biotechnology, 25(2), 185-195.

https://doi.org/10.4014/jmb.1406.06030

Malakar, S., Paul, S. K., \& Jolvis Pou, K. R. (2020). Biotechnological Interventions in Beverage Production. In Biotechnological Progress and Beverage Consumption. Elsevier Inc. https://doi.org/10.1016/b978-0-12-8166789.00001-1

Matsubara, T., Ben Ammar, Y., Anindyawati, T., Yamamoto, S., Ito, K., Iizuka, M., \& Minamiura, N. (2004). Degradation of raw starch granules by $\alpha$-amylase purified from culture of Aspergillus awamori KT-11. Journal of Biochemistry and Molecular Bology, 37(4), 422-428. https://doi.org/10.5483/BMBRep.2004.37.4.422

Miller, G. L. (1959). Use of Dinitrosalicylic Acid Reagent for Determination of Reducing Sugar. Analytical Chemistry, 31(3), 426-428. https://doi.org/10.1021/ac60147a030

Moorthy, S. N. (2002). Physicochemical and functional properties of tropical tuber starches: A review. Starch/Staerke, 54(12), 559-592. https://doi.org/10.1002/1521379X(200212)54:12<559::AIDSTAR2222559>3.0.CO;2-F

Najafpour, G. (2015). Biochemical engineering and biotechnology. Elsevier.

Otache, M., Ubwa, S., \& Godwin, A. (2017). Proximate Analysis and Mineral Composition of Peels of Three Sweet Cassava Cultivars. Asian Journal of Physical and Chemical Sciences, 3(4), 1-10. https://doi.org/10.9734/AJOPACS/2017/36502

Pandey, A., Nigam, P., Soccol, C. R., Soccol, V. T., Singh, D., \& Mohan, R. (2000). Advances in microbial amylases. Biotechnology and Applied
Biochemistry, 31(July 2016), 135-152. https://doi.org/10.1042/BA19990073

Pedersen, H., \& Nielsen, J. (2000). The influence of nitrogen sources on the $\alpha$-amylase productivity of Aspergillus oryzae in continuous cultures. Applied Microbiology and Biotechnology, 53(3), 278-281. https://doi.org/10.1007/s002530050021

Perwitasari, U., Nuryati, N., Melliawati, R., \& Yopi, Y. (2018). Glucoamylase Production by Aspergillus awamori KT-11 In Solid State Fermentation Using Cassava Peel as Substrate. Annales Bogorienses, 21(1), 21. https://doi.org/10.14203/ann.bogor.2017.v21.n1. 21-28

Rodrigues, É. F., Ficanha, A. M. M., Dallago, R. M., Treichel, H., Reinehr, C. O., Machado, T. P., Nunes, G. B., \& Colla, L. M. (2017). Production and purification of amylolytic enzymes for saccharification of microalgal biomass. Bioresource Technology, 225, 134-141. https://doi.org/10.1016/j.biortech.2016.11.047

Saavedra-Leos, Z., Leyva-Porras, C., Araujo-Díaz, S. B., Toxqui-Terán, A., \& Borrás-Enríquez, A. J. (2015). Technological application of maltodextrins according to the degree of polymerization. Molecules, 20(12), 2106721081. https://doi.org/10.3390/molecules201219746

Sani, A., Awe, F. A., \& Akinyanju, J. A. (1992). Amylase Synthesis in Aspergillus-Flavus and Aspergillus-Niger Grown on Cassava Peel. Journal of Industrial Microbiology, 10(1), 5559.

Sindhu, R., Binod, P., \& Pandey, A. (2016). $\alpha$ Amylases. Current Developments in Biotechnology and Bioengineering: Production, Isolation and Purification of Industrial Products, 3-24. https://doi.org/10.1016/B978-0-44463662-1.00001-4

Somogyi, M. (1952). Notes on Sugar Determination. Journal of Biological Chemistry, 19-24.

Souto, L. R. F., Caliari, M., Soares Júnior, M. S., Fiorda, F. A., \& Garcia, M. C. (2017). Utilization of residue from cassava starch processing for production of fermentable sugar by enzymatic hydrolysis. Food Science and Technology, 37(1), 19-24. https://doi.org/10.1590/1678-457X.0023

Sundarram, A., \& Krishna Murthy, T. P. (2014). $\alpha-$ 
Amylase Production and Applications: A Review. Journal of Applied \& Environmental Microbiology, 2(4), 166-175. https://doi.org/10.12691/jaem-2-4-10

Takeiti, C. Y., Kieckbusch, T. G., \& Collares-Queiroz, F. P. (2010). Morphological and physicochemical characterization of commercial maltodextrins with different degrees of dextroseequivalent. International Journal of Food Properties, 13(2), 411-425. https://doi.org/10.1080/10942910802181024

Ubalua, A. O. (2014). Sweet Potato Starch as a Carbon Source for Growth and Glucoamylase Production from Aspergillus niger. September, 788-795.

Uçkun Kiran, E., Trzcinski, A. P., \& Liu, Y. (2014). Glucoamylase production from food waste by solid state fermentation and its evaluation in the hydrolysis of domestic food waste. Biofuel Research Journal Biofuel Research Journal Biofuel Research Journal, 3(3), 98-105.

Wang, Q., Wang, X., Wang, X., \& Ma, H. (2008). Glucoamylase production from food waste by
Aspergillus niger under submerged fermentation. Process Biochemistry, 43(3), 280-286. https://doi.org/10.1016/j.procbio.2007.12.010

Widiharih, T. (2001). Analisis ragam multivariat untuk rancangan acak lengkap dengan pengamatan berulang. Jurnal matematika dan komputer, 4(3), 139-150.

Woiciechowski, A. L., Nitsche, S., Pandey, A., \& Soccol, C. R. (2002). Acid and enzymatic hydrolysis to recover reducing sugars from cassava bagasse: An economic study. Brazilian Archives of Biology and Technology, 45(3), 393400.

https://doi.org/10.1016/j.biortech.2007.07.028

Zhao, W., Nie, Y., Mu, X., Zhang, R., \& Xu, Y. (2015). Enhancement of glucose production from maltodextrin hydrolysis by optimisation of saccharification process using mixed enzymes involving novel pullulanase. International Journal of Food Science and Technology, 50(12), 2672-2681. https://doi.org/10.1111/ijfs.12939 